\title{
New approach for the study of paleofloras using geographical information systems applied to Glossopteris Flora
}

Nova abordagem para o estudo das paleofloras utilizando sistemas de informação geográfica aplicada a Flora Glossopteris

\author{
Isabel Cortez Christiano-de-Souza ${ }^{1 *}$, Fresia Ricardi-Branco ${ }^{1}$, \\ Adalene Moreira Silva ${ }^{2}$, Linda Gentry El Dash ${ }^{3}$, Rafael Souza Faria ${ }^{1}$
}

\begin{abstract}
This paper introduces a methodology which makes possible the visualization of the spatial distribution of plant fossils and applies it to the occurrences of the Gondwana Floristic Province present on the eastern border of the Brazilian portion of the Paraná Basin during the Neopaleozoic. This province was chosen due to the existence of a large number of publications referring to their occurrence, so that a meta-analysis of their distribution could be based on ample information. The first step was the construction of a composite database including geographical location, geology, and the botanical systematics of each relevant fossil. The geographical locations were then georeferenced for translation into various maps showing various aspects of the distribution of the fossils. The spatial distribution of the fossil-housing outcrops shows that these are distributed along the area of deposition studied. Although some genera persisted for long periods of time, others lasted for only short intervals. As time passed, the fossil composition underwent a gradual change from the Late Carboniferous (Itararé Group) to the Late Permian (Rio do Rasto Formation), with the number of genera represented decreasing from 45 in the Itarare Group to 11 in the Rio do Rasto Formation.
\end{abstract}

KEYWORDS: Geographic Information Systems; Gondwana Floristic Province; Paraná Basin; Floristic Maps.
RESUMO: $O$ presente artigo introduz a uma metodologia na qual será possivel a visualização da distribuição espacial de fitofósseis. Tal metodologia será aplicada a ocorrências da Província Florística do Gondwana presente na borda leste da porção brasileira da Bacia do Paraná durante o Neopaleozóico. Essa província foi escolbida tendo em vista que nela há grande número de publicaçôes referentes às suas ocorrências. Isso torna possivel a meta-análise de sua distribuiçāo, uma vez que há ampla gama de informaçóes. O primeiro passo foi a construção de uma base de dados composta, incluindo localização geográfica, geologia e sistemática botânica de cada fóssil de interesse. As informaçôes foram entäo georreferenciadas para posterior transferência em diversos mapas mostrando vários aspectos da distribuiçấo fossilifera. Através de sua distribuição espacial, se pode contatar que os fitofósseis se encontram amplamente distribuidos em toda a área de estudo. No entanto, alguns gêneros persistem por longos periodos de tempo, já outros somente por curtos intervalos. Ao longo do tempo, a composição fossilifera se transformou gradualmente, desde suas primeiras ocorrências no Grupo Itararé (Neocarbonifero), até a Formação Rio do Rastro (Neopermiano), com o número de gêneros decrescendo de 45 no Grupo Itararé para 11 na Formação Rio do Rasto.

PALAVRAS-CHAVE: Sistemas de Informação Geográfica; Província Florística do Gondwana; Bacia do Paraná; Mapas Florísticos.

\footnotetext{
${ }^{1}$ Department of Geology and Natural Resources, Institute of Geocience, Universidade Estadual de Campinas - UNICAMP, Campinas (SP), Brazil. E-mail: isabel.cortez@ige.unicamp.br; fresia@ige.unicamp.br;writetofaria@gmail.com

2Institute of Geoscience, Universidade de Brasilia - UnB, Brasília (DF), Brazil. E-mail: adalene@unb.br

${ }^{3}$ Institute of Language Studies, Universidade Estadual de Campinas - UNICAMP, Campinas (SP), Brazil. E-mail: lindage@terra.com.br

*Corresponding author

Manuscrito ID: 30113. Recebido em: 05/05/2014. Aprovado em: 21/10/2014.
} 


\section{INTRODUCTION}

This paper was designed to provide a meta-analysis of the spatial and temporal distribution of late Paleozoic plant fossils in the Brazilian part of the Paraná Basin. It was based on the composite data reported in the specialized literature and the use of the tools of Geographic Information Systems (GIS, especially the software ArcGIS ${ }^{\odot}$ ), as this made it possible to determine some of the characteristic elements of this Gondwana floristic province.

Although individual fossils are usually treated as independent elements, to be described and listed in an attempt to define biostrategraphic zones, the procedure used here made it possible to generate maps defining overall distribution. What was proposed here was thus the creation of maps showing the location of the Gondwana Floristic Province in the Paraná Basin using the tools of GIS and a survey of the bibliographic publications available. The final results included 1,208 lines of data (each one about a single species in a specific location, found in a total of 281 outcrops), based on the information contained in the references consulted.

These data made it possible to obtain information about the spatial and temporal distribution of these fossil species, as well as identifying interrelationships between the genera and the location where they were found, thus providing a single valid interpretation for the large volume of information available. It is hoped that this will provide a more realistic idea of the evolution of Gondwana Floristic Province at the Paraná Basin, as well as identifying the more prevalent genera of the various time periods, spatial distribution and generating new information about their provenance.

\section{METHODOLOGY}

\section{Theoretical Revision: The Paraná Basin}

The Paraná Basin is an intracratonic basin located on the South American continent; it includes parts of the territory of four countries (Brazil, Paraguay, Argentina, and Uruguay), with a total of 1.5 million square kilometers (Milani et al. 2007). The basin is an ellipse running from NNE-SSW, with its borders at present defined by erosion related to the tectonics of the Meso-Cenozoic ages. The deposition occurred in the interval which stretches from the Late Ordovician (450 Ma) until the end of the Cretaceous (66 Ma).

The sedimentary/magmatic package of the Paraná Basin reaches a maximum depth of 7 thousand meters, where it coincides geographically with the valley of the Paraná River. Figure 1 shows the Brazilian portion of the basin. The location coincides with a series of sedimentary packages indicating a series of marine oscillations, as well as events of subsidence and rising, characteristic of the polycyclic regime of the basin. Milani (1997) has divided the Paraná Basin into six large-scale units or supersequences, defined by layers of rocks encompassing deposition intervals of tens of millions of years, layered between inter-regional discordances These supersequences include the Rio Ivaí (Ordovician - Silurian); Paraná (Devonian); Gondwana I (Carboniferous - Early Triassic); Gondwana II (Middle Triassic - Late Triassic); Gondwana III (Late Jurássic - Early Cretáceous) and Bauru (Late Cretaceous).

The Gondwana I Supersequence contains fossils of the Gondwana Floristic Province (traditionally treated as PreGlossopteris and Glossopteris paleofloras); it is composed of the Itararé, Guatá, and Passa Dois groups, as well as the Pirambóia and Sanga do Cabral Formations. This Supersequence represents the greatest volume of sediments in the Paraná Basin, some 2,500 $\mathrm{m}$ in depth (Milani et al. 2007), and traces a history of marine transgressions and regressions of the glacial period of the Pennsylvanian to the continental environment of the Lopingian.

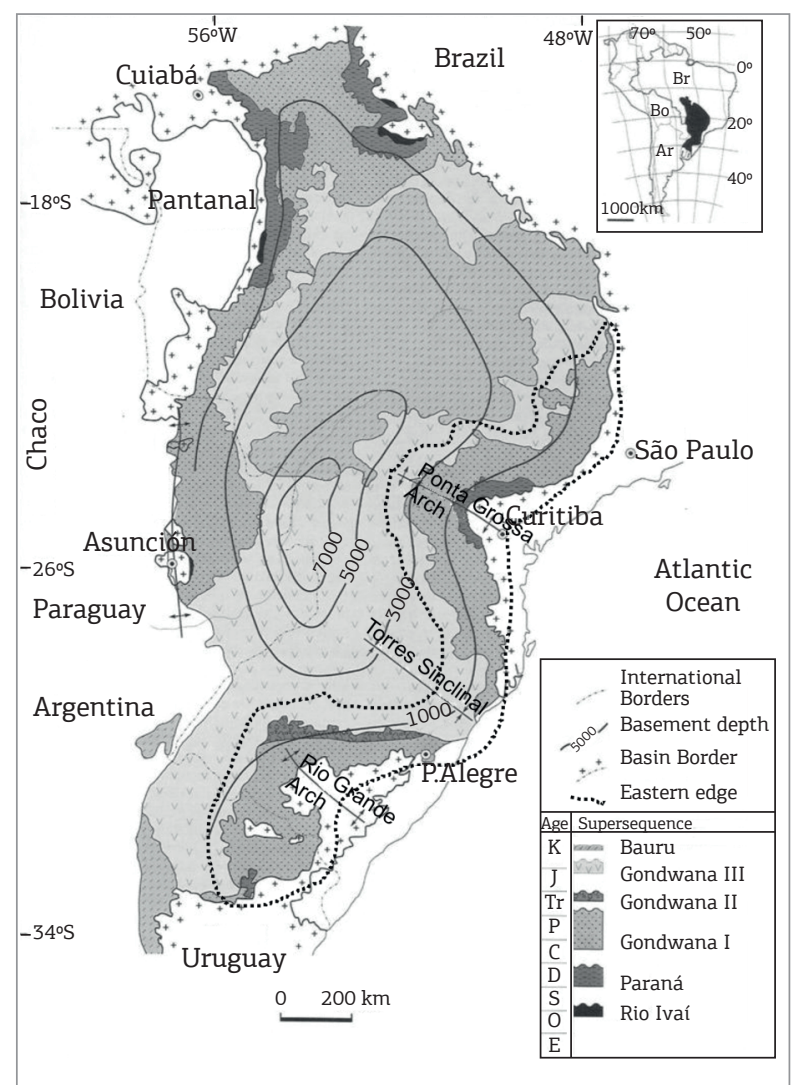

Figure 1. Geological map of the Brazilian portion of the Paraná Basin, showing the structural outline depth of the crystalline basement. The sequence studied here (Gondwana I) is outlined with the dotted line. (modified from Milani 2004). 
During the Late Carboniferous, the southern part of the paleocontinent of Gondwana was located at a higher latitude (greater than $60^{\circ}$ South), a context of extensive continental glaciations which is reflected in the deposition of the Itararé Group in the Paraná Basin. The progressive migration of the paleocontinent to lower northern latitudes during the Permian led to a series of climatic changes, with the melting of the ice accompanied by the consequent rise in relative sea level (Permian transgression) (Rees 2002; Milani et al. 2007).

Later in the Permian, a decrease in the relative sea level led to the formation of an inland sea, with a limited circulation of water and a gradual hypersalination of the environment associated with isolated shallow bays, which is reflected in the deposits of organic material in an anaerobic environment in the Passa Dois Group. Still later, during a large-scale regression, a continental system developed, with sedimentation eventually leading to the complete filling of the basin during the Guadalupian and the installation of semi-arid or desertic sedimentary environments at the end of the Permian and beginning of the Triassic (Milani et al. 2007).

The macrophyte fossils found in this supersequence have been studied by the scientific community since the eighteenth century. Collected, described and included in the collections of the larger museums, they have contributed much to our knowledge of the evolution of plant communities. They furnish a clear picture of the plant life on southwestern portion of the supercontinent of Gondwana during the end of Paleozoic Era.

\section{The Map Construction}

This paper provides a composite database about plant fossil occurrences reflecting a compilation of information furnished by three types of sources: (a) reports about Carboniferous and Permian macrophyte fossils found in a review of 100 years of bibliographic references; (b) information about geology supplied by the geologic map of Brazil (scale of 1:100000), furnished by the Geological Service of Brazil (CPRM); and (c) information about altitude furnished by the Shuttle Radar Topography Mission (SRTM) of the American National Aeronautics and Space Administration (NASA). This compilation has made it possible to construct maps showing the distribution of plant fossils in the Paraná Basin using ArcGIS ${ }^{\circ}$ software. Details of the three elements are discussed below.

\section{Bibliographic references}

Initially, an attempt was made to recuperate as much data as possible about plant fossils in the Late Carboniferous and Permian in the Paraná Basin. In addition to the traditional foreign sources (Derby 1915, Lundqvist 1919, Florin 1940, Rao 1940), an extensive survey was made of articles, books, and theses available in Brazil. A total of 158 references published in a period of more than a hundred years were located, reviewed and analyzed.

\section{Geologic map of the Geological Service of Brazil (CPRM)}

The Geological Map of Brazil (scale of 1:1000000), with pages in the form of vectorial archives (shapefiles), is available for download from the Geobank database of the CPRM (http://geobank.sa.cprm.gov.br/) (CPRM 2004).

The outcrops of Gondwana I on these pages of the Geological Map of Brazil are generally those found in the southern and southeastern part of Brazil (below the latitude of $20^{\circ}$ South), i.e., pages SF21-SF24, SG21-SG23, SH21$\mathrm{SH} 22$, and S122. These pages were united in a single vectorial archive using $\operatorname{ArcGIS}^{\bullet}$ software.

\section{SRTM Mosaic}

The SRTM altimetric data utilized here were generated using Interferometry Synthetic Aperture Radar (InSAR) technology, operating with antennas for the $\mathrm{C}$ and $\mathrm{X}$ bands (Carneiro 2005, Rabus et al. 2003). These data, presented as a Digital Model of Elevation with a spatial resolution of $3 \operatorname{arcsec}(-90 \mathrm{~m})$ and a radiometric resolution of 16 bits for South America, were collected between the days of February 11-22, 2000. This information was made available by NASA on the electronic address ftp://edcsgs9.cr.usgs.gov/pub/data/ srtm/South_America.

\section{The Composite database}

The composite database developed here is presented in a simple model, known as a hierarchic model, which has often proved useful in the natural sciences (Burrough 1986). This database was developed on the basis of four key attributes: (a) geographical outcrop; (b) geological information based on lithostratigraphy, geochronology, flora, environment of deposition, (c) paleobotany (systematics and data about the fossils); (d) and bibliographic references.

\section{Outcrop}

The first group of attributes is related to the general data about the spatial location of the outcrop, including:

- Name: Outcrop names generally make reference to the geographical location, or they are identified by numbers, as defined by the author of a study or collection.

- Municipality and State: Municipalities and states are directly related to the location of outcrops. Since the data base was limited to a survey of plant fossils in Brazilian territory, only those states having such 
outcrops from the Late Carboniferous - Permian interval on the eastern edge of the Brazilian portion of the Paraná basin were considered (Rio Grande do Sul, Santa Catarina, Paraná, and São Paulo) and the municipalities are those in these states where fossil-bearing outcrops have been identified.

- Coordinates: The coordinates utilized are those presented in the articles, theses, congress abstracts, etc. consulted. When exact coordinates of locations were not mentioned in the original reference, these were inferred by the use of a map portraying georeferenced highways or hybrid georeferenced satellite photographs showing georeferenced roads and geographical coordinates. All coordinates are reported to the specification of a single decimal place (various possible maps are available, such as WikiMapia - (http://wikimapia.org) and ACME Mapper - (http://mapper.acme.com). When the authors did not report exact locations, the central point of the municipality was used, with the lithology being considered as carefully as possible. The datum for the maps of Geomapas, as well as for most of the coordinates cited, was reported for the "Córrego Alegre" datum. For those in the CPRM, the datum was SAD69.

\section{Geological information}

The geology of the composite database considered the geological attributes of the outcrops of the Gondwana I Supersequence along the eastern edge of the Paraná Basin, in which the paleofloras of the Late Carboniferous-Permian interval are recorded. The information in the key was limited to location in the Itararé, Guatá, and Passa Dois groups, with their composite formations, without mention of specific lithology and lithofacies present in each outcrop, since multiple lithologies can be found in a single outcrop.

- Lithostratigraphy: The Gondwana I Supersequence is composed of what is today known as the Itararé, Guatá, and Passa Dois groups, as well as the Pirambóia and Sanga do Cabral formations (Milani et al. 2007) (Fig. 2). The names of groups, formations, and members reported in the original articles, however, did not always correspond to this usage, and certain adaptations were necessary to accommodate changes in terminology of the lithostratigraphy of the basin throughout the years.

- Geochronology (Períod, Epoch and Age): The information about geological age reflects the work of Milani et al. (2007) for the stratigraphy of the Paraná Basin, with the geologic age of each formation used as a point of reference.

- Flora: Usually the Gondwana Floristic Province for the Paraná basin is divided into the Pre-Glossopteris and Glossopteris paleofloras, with the latter divided into 5 subdivisions (Fig. 3) (Rösler 1978, Rohn \& Rösler 2000, Rees 2002, Iannuzzi \& Souza 2005, Azcuy et al. 2007). The Pre-Glossopteris Paleoflora

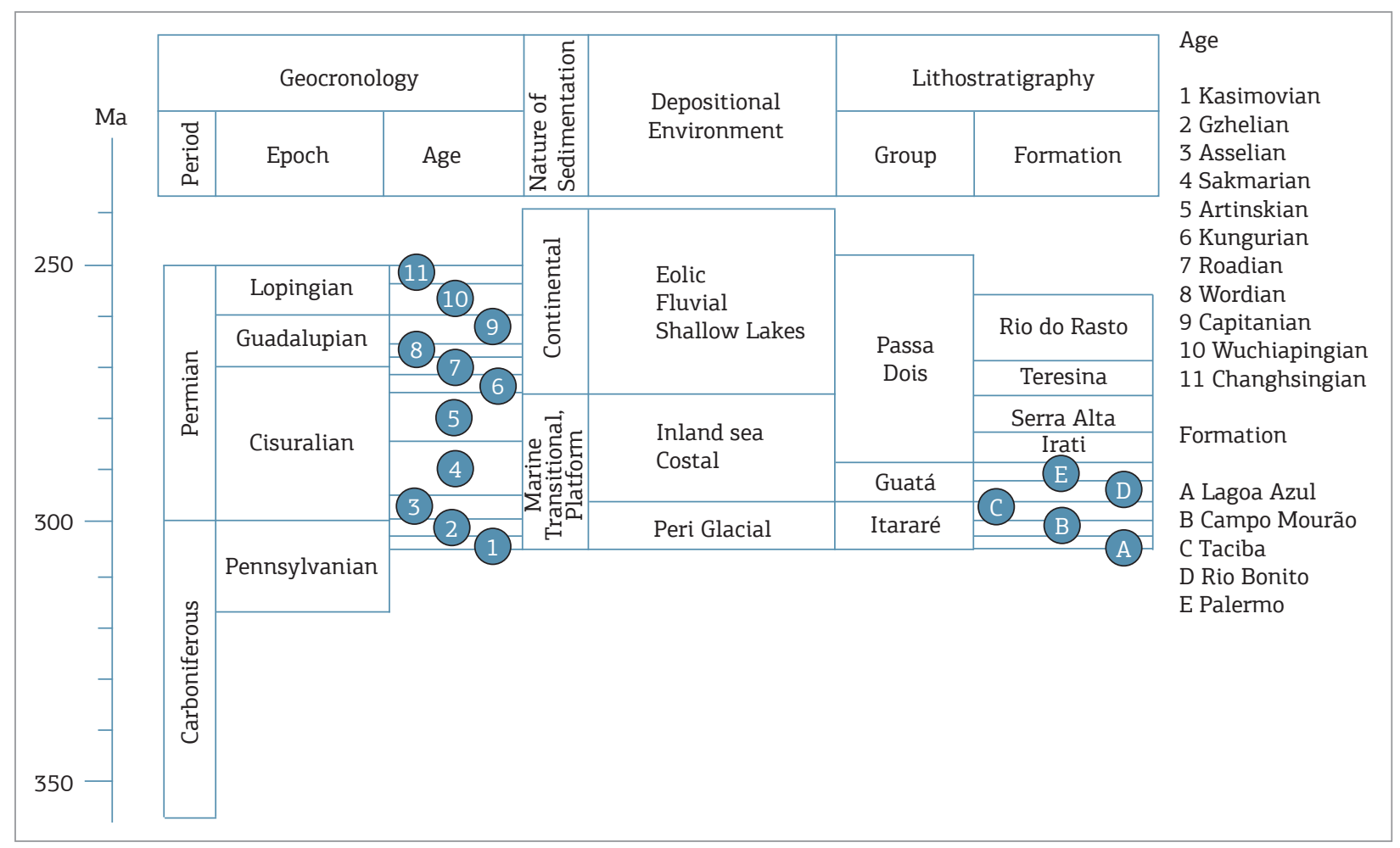

Figure 2. Stratigraphic column of the Late Paleozoic in the Paraná Basin (Modified from Milani et al. 2007). 
(Azcuy et al. 2007) is what is found in outcrops of the basal portions of the Itararé Group and is characterized by species of the following genera: Gangamopteris, Rubidgea, Samaropsis, Botrychiopsis, Cordaicarpus, and Paracalamites. These fossils are overlain by those of the first subdivision of the Glossopteris Paleoflora, the Phyllotheca-Gangamopteris flora (found at the top of the Itararé Group and in the lower layers of the Rio Bonito Formation), which includes the first register of the genus Glossopteris, while Gangamopteris predominates. The second subdivision consists of the Glossopteris-Brasilodendron flora of the central and upper layers of the Rio Bonito Formation, the flora with the greatest diversification of genera in the basin, in which Gangamopteris decreases, while Glossopteris increases in abundance. The third subdivision, the Polysolenoxylon-Glossopteris flora, is found in the overlying Irati Formation; which includes various registers of fossilized wood in addition to plants of the genera of Glossopteris. The more recent flora is traditionally divided into various plant zones, each housing a predominance of specific species/genera (Rohn \& Rösler 2000), but here these are designated as flora. The first, the Lycodiopsis derbyi flora, registered in the Teresina/ Corumbataí formations, reveals principally lycopsids, but also some equisetopsids, "pteridosperms", and the predominant Glossopteris, although the Gangamopteris have disappeared from the fossil record. The second of these is denominated the Sphenophyllum/Schiunozeura flora and includes the Sphenophyllum paranaense and Schinozeura gondwanensis plant zones, found only in the Serrinha Member of the Rio do Rasto Formation and in the Morro Pelado Member, respectively, and the number of species of Glossopteris has been surpassed by that of Paracalamites.
Paleoenvironment: The depositional environment suggested by the geological formation is included in the data base, following the proposal of Milani et al. (2007) (Fig. 2). This attribute can then be compared with the environment characteristic of each plant species.

\section{Paleobotany}

The third group of attributes included in the key involves botanical information about the fossils included in the database, as well as data about their systematics, structures, process of fossilization involved, and possible transport.

- Paleontological systematics: The systematics defined by the author are included, as well as the tendencies suggested by the present-day division of the plant kingdom and the most recent modifications in the classification and identification of plant fossils. The system of classification used in the composite database was based on Frey (2009) and Taylor et al. (2008).

Structures preserved: Various kinds of plant vestiges were reported, including vegetative organs, such as leaves, stems, branches, trunks, and roots, as well as reproductive organs (including seeds and sporangia). This information can be useful because it can provide an indication of whether or not a specific structure could have been transported for a long distance.

Type of preservation: The type of preservation refers to the process of fossilization and to the material of which the fossil is composed. The plant fossils present in the Paraná Basin consist of compressions, impressions, and permineralizations.

- Environment suggested by the botany of taxa: The information about environment suggested by the characteristics of a taxon may be different from that suggested by geology. Geology interprets the environment as a whole, generally by consideration of sedimentary

\begin{tabular}{|c|c|c|c|c|c|c|c|}
\hline \multirow{10}{*}{ 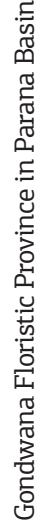 } & & & \multicolumn{2}{|l|}{ Azcuy et al. (2007) } & This work* & \multicolumn{2}{|l|}{ Geologic Unit } \\
\hline & \multirow{8}{*}{ Glossopteris Flora } & \multirow{3}{*}{$\begin{array}{l}\text { D: } \\
\text { d: } \\
\text { है: }\end{array}$} & Schinozeura gondwanensis & \multirow{3}{*}{ 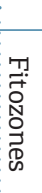 } & Schinozoura Snhononhullum & Bindo Racto Formation & \multirow{5}{*}{ 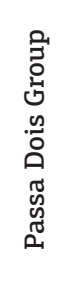 } \\
\hline & & & Sphenophyllum paranaense & & 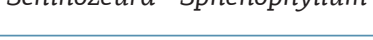 & 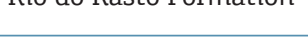 & \\
\hline & & & Lycopodiopsis derbyi & & Lycopodiopsis derbyi & $\begin{array}{l}\text { Teresina Formation } \\
\text { Corumbataí Formation }\end{array}$ & \\
\hline & & \multirow{6}{*}{$\begin{array}{l}\text { 忠: } \\
\text { 恶: }\end{array}$} & Hiatus & & Hiatus & S. Alta Formation & \\
\hline & & & Polysolenoxylon-Glossopteris & & Polysolenoxylon-Glossopteris & Irati Formation & \\
\hline & & & Hiatus & & Hiatus & Palermo Formation & \multirow{3}{*}{ 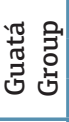 } \\
\hline & & & Glossopteris-Brasilodendron & & Glossopteris-Brasilodendron & Rio Bonito Formation & \\
\hline & & & Phyllotheca-Gangamopteris & 雫 & Phyllotheca-Gangamopteris & Tatuí Formation & \\
\hline & $\begin{array}{l}\text { Pre Glossopteris } \\
\text { Flora }\end{array}$ & & Pre-Glossopteris & & Pre-Glossopteris & Itararé Group & \\
\hline
\end{tabular}

Figure 3. Division of plant succession found in the Paraná Basin during the Late Paleozoic, and the respective geological units where they were found. 
features (lithology, granulometry, geologic structures, etc.) and offers a general panorama, rather than exact information about a specific location. Fossils, however, especially autochthonous and parautochthonous, furnish information about a more specific location, since plants are stationary and intimately linked to the interaction of conditions such as climate, humidity, and illumination (Tab. 1).

- Possible distance transport: This category indicates the possible spatial displacement of a specimen from its original habitat to the location of deposition. This was classified by the separation of the original plants into (a) fragile plants or structures which could not have withstood transport for long distance; (b) those which could have withstood limited transport; and (c) more resistant plants or structures, which are frequently transported for long distances and deposited outside their normal habitat. The latter, such as seeds and trunks, are very resistant plant structures that could have been transported throughout the basin, and their presence would not be a good paleoenvironmental indicator, although the presence of fragile structures such as leaves, which would at least be broken down if subject to transport, suggests deposition at or close to the point of origin.

\section{RESULTS}

The three maps presented (Figs. 4, 5a, 5b) are representative of the kinds of information obtainable using the proposed methodology.

Table 1. Ratio of plant species $\mathrm{x}$ environment with the greatest probability of development.

\begin{tabular}{|c|c|}
\hline Types of plants & Environment \\
\hline $\begin{array}{l}\text { Coniferous, Cordaitales } \\
\text { and others gymnosperms }\end{array}$ & Outside the Basin (allochthonous) \\
\hline Seed Ferns & $\begin{array}{l}\text { Floodplain - outside the depositional } \\
\text { area (probably allochthonous) }\end{array}$ \\
\hline Ferns & $\begin{array}{l}\text { margins of water bodies - } \\
\text { floodplain }\end{array}$ \\
\hline Sphenophytes & Floodplain \\
\hline Lycophytes & Margin of water bodies - Marshes \\
\hline $\begin{array}{l}\text { Bryophytes and } \\
\text { marchantiophytes }\end{array}$ & Margin of water bodies - Swamps \\
\hline Algae & Inside the water bodies \\
\hline Incertae sedis & $?$ \\
\hline
\end{tabular}

Mapping the distribution of the fossils of different floras (Fig. 4) makes it possible to trace the changes in flora with changes in climate, as revealed by the geology of the region. The lack of Pre-Glossopteris fossils in the central and southern portions of the Paraná Basin was to be expected, since during the Carboniferous this part of Gondwana was located close the South Pole and is assumed to have been covered by ice, precluding the development of plant communities (Veevers 2004). However, the most common map (Scotese 2001) of Carboniferous Gondwana also shows the northern portion covered by ice, yet the presence of Pre-Glossopteris fossils proves that at least part of the time, this region was uncovered and had conditions for the development and flourishing of plants.

The map also shows that at the end of the Permian, which has been interpreted as having a dry, desertic climate, plants still flourished, at least in certain regions, probably the deeper parts of the basin.

The second map (Fig. 5a) emphasizes this conclusion. It maps the occurrences of the fossils of the genera Paracalamites, Sphenophyllum, and Schizoneura, which flourish in humid environments. This mapping reveals regions which were probably swampy during the Late Carboniferous-Permian interval, despite the overall aridization of the region, the central portion of the basin reveals a large concentration of plant fossils. These wet spots may have represented the deepest portions of the basin, with the relatively calm and shallow waters still remaining, thus permitting the deposition and burial of fragile leaves and stems without destruction during transportation.

The third map (Fig. 5b) identifies geographical features such as paleodrainage patterns, which are indicated by the concentration of possibly allochthonous plant debris. The fossils of possibly the genera of allochtonous plants were plotted in circles with a radius of about $10 \mathrm{~km}$, which was considered to correspond to a distance which resistant plants and fragments, such as trunks and seeds, could have been transported (Spicer 1980, Ricardi-Branco et al. 2009). Many of these areas overlie each other for the different floras in different time periods, i.e., the locations of deposition during different periods are the same, which suggests that, despite the decrease in water level in the basin throughout the Permian, the zones most propitious for the deposition of plants did not change much.

In the northern part of the basin, a certain N-S vertical tendency in areas where different floras were deposited can be seen. This line suggests the location of an ancient river mouth during a period of regression. Plant fragments needing greater energy for transport tend to 
be deposited in such locations. Since the older plant fossils are found further to the south and the newer ones to the north, it seems that as regression progressed, the mouth of a river and its associated deposits retreated northward, for a distance of more than $150 \mathrm{~km}$ during the Late Carboniferous - Late Permian interval.

\section{CONCLUSIONS}

The methodology proposed here which uses georeferenced paleontological data for the development of thematic maps of the succession of some five floras over an extended time period of 60 million years has proved to be efficient for the interpretation of the distribution and composition of plant communities in the Paraná Basin and the identification of the paleoenvironment where they flourished. Moreover, these data can be reworked, or other analyses included and superposed, to open to a spatial representation different from what would be expected from a traditional analysis of the data in isolation, such as the discovery of the regression of the paleoriver mouth revealed in the Fig. $5 \mathrm{~B}$, thus providing an even more complete composite picture of the past. This continuous record of the fossils of five floras of Gondwana has permitted the perception of their succession during this period of intense paleoclimatic and paleogeographic changes in which the vegetation of the Paraná Basin suffered alterations in composition and physiognomy.

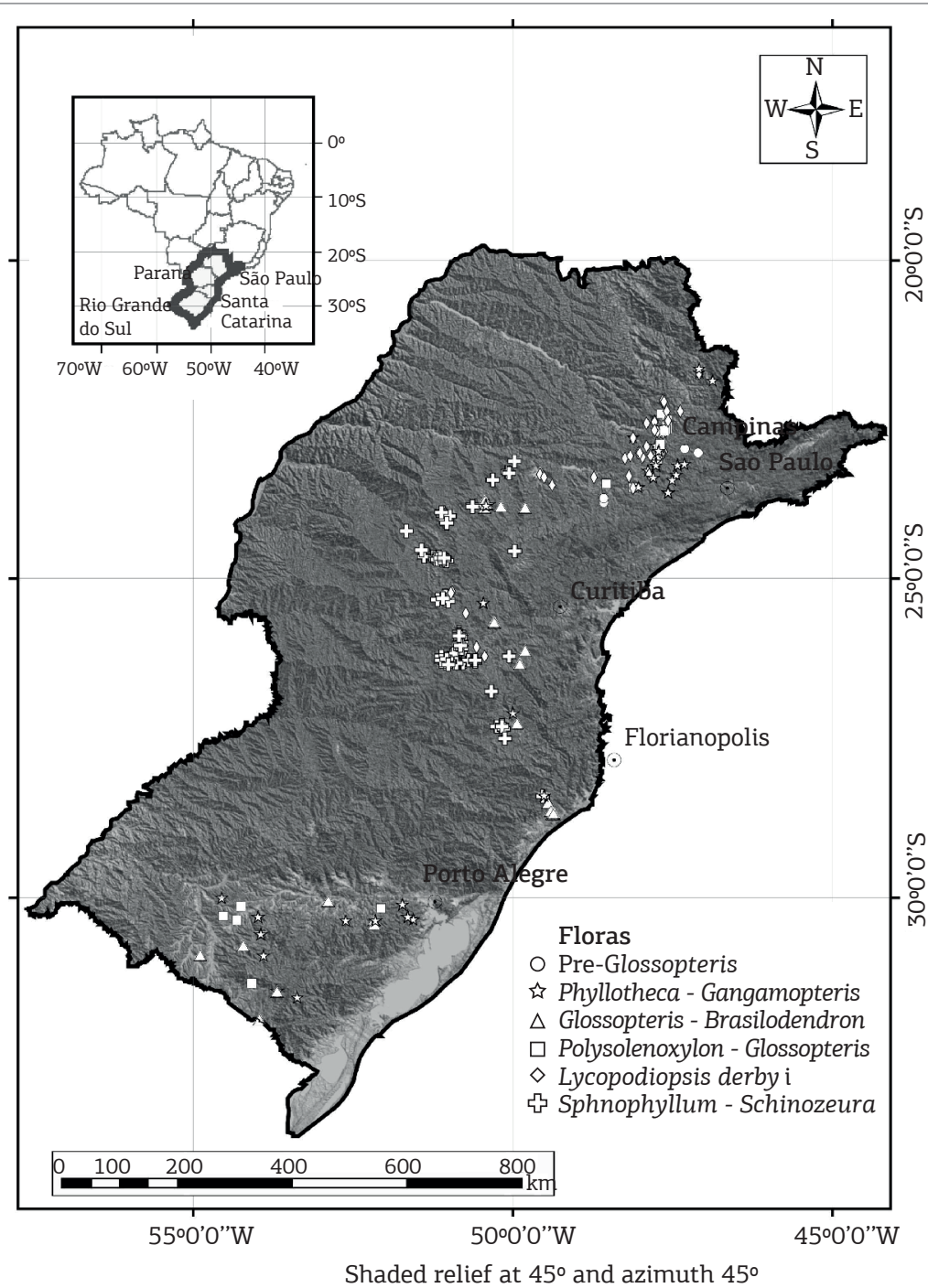

Figure 4. Map of the distribution of outcrops by floras in the Paraná Basin. (CPRM 2004 - Shaded relief at $45^{\circ}$ and azimuth $45^{\circ}$ ). 


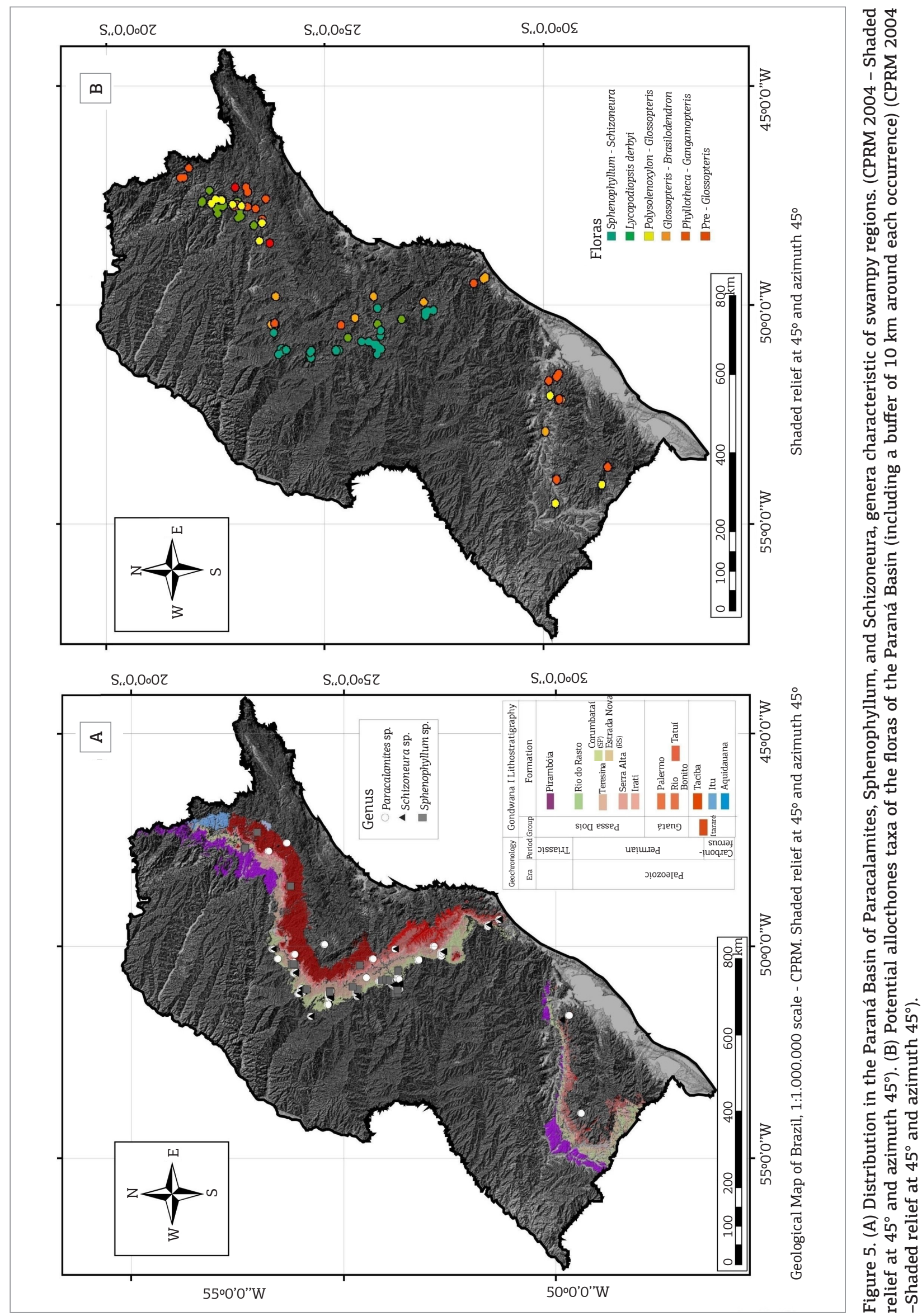




\section{ACKNOWLEDGEMENTS}

The authors would like to acknowledge the collaboration of the Foundation for the Support of Research of the State of São Paulo (Fapesp), which provided a master's fellowship 2009/04418-4, as well as funds for conducting the research project 2009/10547-1 "Paleophytogeography and fossil woods from Paraná Basin during Late Paleozoic", and CNPq by researcher grant.

\section{REFERENCES}

Azcuy C.B.A., Beri A., Bernardes de Oliveira M.E.C., Carrizo H.A., Di Pasquo M, Saraiva P.D., Gonzales C., Iannuzzi R., Lemos V.B., Melo J.H.G., Pagani A., Rohn R., Amenabar C.R., Sabbatini N., Souza P.A., Taboada A., Vergel M.M. 2007. Bioestratigrafia del Paleozoico Superior de América del Sur: Primera etapa de trabajo hacia una nueva propuesta cronoestratigráfica. Publicaciónes Especiales de la Asociación Paleontológica Argentina, 11:9-65.

Burrough P.A. 1986. Principles of Geographical Information Systems for Land Resources Assessment. Oxford, Oxford University Press, $54 \mathrm{p}$.

Carneiro C.C. 2005. Interpretação de dados de sensores remotos e aerogeofísicos como ferramenta na análise estrutural da área centro-oeste do Sistema Transcorrente Carajás (PA). MS Dissertation, Instituto de Geociências, Universidade Estadual de Campinas, Campinas, $100 \mathrm{p}$

Compania de Pesquisas de Recursos Minerais (CPRM). 2004. Carta Geológica do Brasil ao Milionésimo: sistema de informações geográficas-SIG, escala 1:1.000.000. Brasília, Ministério de Minas e Energia.

Derby O.A. 1915. Illustrations of the Stem structure of Tietea singularis. American Journal of Science, 39:251-260

Florin R. 1940. Die Koniferen des Oberkarbons und des unteren Perms. Palaeontographica Abteilung B, 85:243-363.

Frey A. 2009. Syllabus of Plants Families. Bryophytes and Seedless Vascular Plants. 13 ed., Berlin, Gebrüder Berntraegen, 419 p.

Iannuzzi R. \& Souza P.A. 2005. Floral succession in the Lower Permian deposits of the Brazilian Paraná Basin: an up-to-date overview. New Mexico Museum of Natural History and Science Bulletin, 30:144-149.

Lundqvist, G. 1919. Fossile Pflanzen der Glossopteris Flora aus Brasilien. Kungl Svenska Vetenskaps-Akademiens Handlingar, 60:1-36.

Milani E.J., Melo J.H.G., Souza P.A., Fernandes L.A., França A.B. 2007. Bacia do Paraná. Boletim de Geociências da Petrobras, 15(2):265-287.

Milani E.J. 1997. Evolução Tectono-Estratigráfica da Bacia do Paraná e de seu Relacionamento com a Geodinâmica Fanerozóica do Gondwana Sul-Ocidental, PhD Thesis, Universidade Federal do Rio Grande do Sul, Porto Alegre. 255 p.
Milani E. (2004). Comentários sobre a origem e a evolução tectônica da Bacia do Paraná. In: Mantesso-Neto V., Bartorelli, A., Carneiro C.D.R., Brito-Neves B.B. (org). Geologia do Continente Sul-Americano: Evolução da Obra de Fernando Flavio Marques de Almeida. São Paulo: Ed. Beca, p. 265-279.

Rabus B., Eineder M., Roth A., Bamler R. 2003. The Shuttle Radar Topography Mission - a New Class of Elevation Models Acquired by Spaceborne Radar, Journal of Photogrammetry \& Remote Sensing, 57:241-262.

Rao H.S. 1940. On the anatomy of Lycopodiopsis derbyi renault with remarks on the Southern Palæozoic Lycopods. Proceedings of the Indian Academy of Sciences - Section B, 11(5):197-217.

Rees P.M., Ziegler A.M., Gibbs M.T., Kutzbach J.E., Behling P., Rowley D.B. 2002. Permian phytogeographic patterns and climate data/ model comparisons. Journal of Geology, 110:1-31.

Ricardi-Branco F., Branco F.C., Garcia R.F., Faria R.S., Pereira S.Y., Portugal R., Pessenda L.C., Pereira P.R.B. 2009. Features of plant accumulations along the Itanhaém River, on the southern coast of the Brazilian state of São Paulo. PALAIOS, 24(7):416-424.

Rohn, R. \& Rösler O. 2000. Middle to Upper Permian phytostratigraphy of the Eastern Paraná Basin. Revista da Universidade de Guarulhos, 5:69-73.

Rösler O. 1978. The Brazilian eogondwanic floral succession. Boletim IG - USP, 9:85-90.

Scotese C.R. 2001. Atlas of Earth History. Texas, Arlington, vol. 1, $52 \mathrm{p}$.

Spicer R.A. 1980. The importance of depositional sorting to the biostratigraphy of plant megafossils. In: Dilcher, D.L., Taylor, T.N. (eds.) Biostratigraphy of Fossil Plants: Successional and Paleoecological Analyses. Pennsylvania, Hutchinson \& Ross, p. $171-183$

Taylor T.N., Taylor E.L., Krigs M. 2008. Paleobotany: The biology and Evolution of Fossil Plants. Amsterdam, Elsevier Inc, 1252 p.

Veevers J.J. 2004. Gondwanaland from 600-570 Ma assembly through $320 \mathrm{Ma}$ merger in Pangea to 185-100 Ma breakup: supercontinental tectonics via stratigraphy and radiometric dating. Earth-Science Reviews, 68(1-2):1-132. 